\title{
ENHANCING STUDENTS' SPEAKING ABILITY THROUGH COLLABORATIVE LEARNING AT AL MAULIDIYAH ORPHANAGE IN JATIASIH BEKASI
}

\author{
Sri Supeni ${ }^{1}$ \\ Sekolah Tinggi Bahasa Asing LIA \\ sri.supeni@stbalia.ac.id \\ Ilham Dhony Pribadi \\ pribadi.dhony@gmail.com
}

\begin{abstract}
Supeni, S. and Pribadi, I.D. (2021). Enhancing Students' Speaking Ability through Collaborative Learning at Al Maulidiyah Orphanage in Jatiasih Bekasi. Journal of English Language and literature, 6(2), 41-50. doi: 10.37110/jell.v6i2.123
\end{abstract}

Received: 12-07-2021

Accepted: 20-08-2021

Published:03-09-2021

\begin{abstract}
The aim of this research was to see the improvement of the EFL learners' speaking ability through the implementation of Storytelling Strategy using pictures. This research was also directed to explore the beneficial of collaborative learning for students of Al Maulidiyah Orphanage in Jatiasih Bekasi. The subject consisted of 15 of EFL learners. A Classroom Action Research in two cycles had been conducted within 2 meetings for every cycle. The meetings were focused on the interactivity and communicative ability among learners. The research result showed that the learners' fulfillment of the storytelling task improved from $40 \%$ or $66.7 \%$. It also showed that the learners' ability in speaking performance improved. The highest improvement was seen from fluency indicator that is from $26.7 \%$ to $46.7 \%$. While for the other two indicators namely pronunciation and vocabulary move upward a little. In conclusion, the implementation of Interactive Storytelling Strategy increased the EFL learners' fulfillment of the storytelling task and their speaking ability.
\end{abstract}

Keywords: collaborative learning, storytelling fulfillment, speaking ability.

\section{INTRODUCTION}

Language is a very important communication tool in transferring or receiving ideas and thoughts from a speaker to a listener. With language what is in the speaker's thoughts can be clearly expressed so that the listener or receiver can understand the intent of the speaker. If the relationship between the two parties is carried out, it can be said that communication is taking place.

If the language used to communicate between the speaker and the listener is the mother tongue, then there won't be many problems. However, if the language used to communicate is a foreign language, there will likely be problems. Problems that may arise include the pronunciation and articulation, understanding supported by mastery of vocabulary and grammar, and also fluency. One foreign language that has become an international language is English. English used as an oral communication tool is widely used in daily communication. Jack C. Richards in his book Methodology in Language Teaching (2002) said

${ }^{1}$ Corresponding Author 
that the biggest presentation of foreign language learners in the world was English learners. Where their goal of learning English is to develop speaking skills, in addition to several other language skills which are listening, reading, and writing. The four skills will be better if accompanied by the ability to master vocabulary and grammatical knowledge that is sufficient as described earlier.

Speaking is one of the important skills for effective communication especially when the speaker is not using his native language. English as a language that is used as a universal communication tool today needs to be improved together with other language skills so that this integrated skill can improve the ability to speak both the language user as a native speaker and a foreign speaker. Bailey (2005) and Goh (2007) argue that speaking ability can be developed by preparing several things appropriately such as: syllabus design, teaching principles, types of assignments and teaching materials, and speaking evaluation itself.

Speaking is one of the important skills for effective communication especially when the speaker is not using his native language. English as a language that is used as a universal communication tool today, needs to be improved together with other language skills so that this integrated skill can improve the ability to speak both the language user as a native speaker and a foreign speaker. Bailey (2005) and Goh (2007) argue that speaking ability can be developed by preparing several things appropriately such as: syllabus design, teaching principles, types of assignments and teaching materials, and speaking evaluation itself.

Al Maulidiyah Orphanage as a foundation engaged in religious education opens boarding schools for orphans and poor people to be given religious education. In addition, children also learn a foreign language, that is Arabic. To improve the quality of education, especially foreign language (Arabic), the foundation also provides English language education. Children are accustomed to making short lectures in both Indonesian and Arabic. Therefore, English which is also being taught at this foundation also tries to train children to speak even though not in the form of lectures but in the form of stories (storytelling).

\section{LITERATURE REVIEW}

\section{Concept Of Speaking}

There are four skills in English: listening, reading, writing, and speaking. Speaking is an expression of human being through conversation. Speaking is a skill which is simply needed more than one person as speaker and listener. This is concluded by the statement of Brown (2004). He defined speaking as a productive skill that can be directly and empirically observed, those observations are invariably colored by the accuracy and effectiveness of a test-taker listening skill, which necessarily compromises the reliability and validity of an oral production test. From those statements above, the writer can conclude that speaking is an activity involving two or more people in which the participants are both the listeners and the speakers having to act what they listen and make their contribution at high speed. Lado (1977) says also that either four or five components are generally recognized in analysis of speech process. They are: a) Pronunciation (Including the segmental featuresvowels and consonant and the stress and intonation/ pattern), b) Grammar, c) Vocabulary, d) Fluency (the case and the speech of the flow of speech), and e) Comprehension. (Lado in Kusmaryati, 2009).

The explanation from Lado, shows that speaking needs process. The result of speaking can be marked in many appraisals, such as pronunciation, grammar, vocabulary, fluency, and comprehension.

\section{Importance Of Speaking}

Speaking ability in English is useful in many situations and places in this era. Such as in the school education, apply to get a job, or when someone goes to the other country, because English is international language. The importance of speaking was mentioned below: Speaking skill is the most important thing to be mastered when people learn English because speaking is a process 
of constructing meaning; it covers almost all of language components. Through speaking someone can express their minds, ideas, and thought freely and spontaneously. In addition, purpose of teaching speaking is to guide both the teachers and students to use the target language as a common language in teaching learning process even in their daily life.

The importance of the ability to speak or write English has recently increased significantly because English has become the de facto standard. Learning the English language has become popular for business, commerce and cultural reasons and especially for internet communications throughout the world. English is a language that has become standard not because it is widely used by many information and technology industries and recognized as being standard. The call center phenomenon has stimulated a huge expansion of internet related activity establishing the future of India a cyber-technological super-power. Modern communications, videos, journals and newspapers on the internet use English and have made knowing English indispensable. (Ahmad, 2016) Guoqiang (2009) stated that: to be a good speaker the English learners have to master all of the components. However, besides those linguistic components above there are many factors that influence speaking ability. Although speaking has been included in the educational plan for English teaching in colleges and universities in the past years, the percentage of time devoted to activities in which students can communicate with each other in English remains small in the whole class. Speaking is the skill that the students will be judged upon most in real-life situation. It is an important part of everyday interaction and most often the first impression of a person is based on his/her ability to speak fluently and comprehensibly.

Speaking is the main way for people to interact and communicate with each other as social creatures where they can express their ideas and communicate what they want orally. Speaking English in this global era is very important because we are able to communicate with other people from various countries in the world. This is in line with what Aye and Phyu said in their book Developing students' speaking skills through short stories (2015) that we really need effective speaking skills in all aspects of life, especially in this global era.

Speaking is described as an interactive process of constructing meaning by the shared information. It depends on the situation or context, includes the physical environment and collective experiences. Speaking does not only express how to produce specific points of language such as pronunciation, vocabulary, or grammar. It shows how people understand when, why, where, and in what ways to produce voice as speaking action.The ability to speak a foreign language in this case, according to Tahir (2015), is the benchmark for the success of a learning process when the learner has the ability to speak. Whereas Sepahvand (2014) argues that there are several reasons for placing speaking ability as the main goal of learning such as personal satisfaction because of being able to speak and achieve other interests or careers.

\section{Speaking Problems}

There are some causes that make speaking quite difficult for some people. Different type of person will face different problems in speaking since speaking is considered as a complex skill involving both intrinsic and extrinsic aspects as what Brown (2001) stated that there were some causes which make speaking quite difficult such as: clustering, redundancy, reduced forms, performance variables, colloquial language, rate of delivery, stress, rhythm and intonation, and interaction.

\section{Clustering}

Clustering is a fluent speech in the form of phrasal, not word by word. The learners can organize their output both cognitively and physically (in breath groups) through such clustering.

\section{Redundancy}

Through the redundancy of language the speaker can make the meaning much clearer and they can capitalize on this feature of spoken language.

\section{Reduced Forms}

There are some problems in teaching spoken English such as contractions, elisions, reduced 
vowels, etc. If the learners do not learn colloquial contractions, they can sometimes develop a stilted, bookish quality of speaking or even stigmatize them.

\section{Performance Variables}

One advantage of spoken language is that the process of thinking as the learners speak allow them to manifest a certain number of performance hesitation, pauses, backtracking, and corrections. They can actually be taught how to pause and hesitate. For instance, in English when the speakers speak, their thinking time is not silent; they insert certain fillers such as um, ub, well, I mean, you know, like, etc. This hesitation phenomena is one of the most salient differences between native and nonnative speakers.

Colloquial Language

The learners must be reasonably well acquainted with the words, idioms, and phrases of colloquial language and practice producing these forms.

Rate of Delivery

Rate of delivery is another salient characteristics of fluency. One of the teacher's tasks in teaching spoken English is to help the learners achieve an acceptable speed along with other fluency attributes.

Stress, Rhythm, and Intonation

These three factors - stress, rhythm, and intonation

- become the most important characteristics of English pronunciation and can convey important messages.

Interaction

The creativity of conversational negotiation as the speaking skill's richest component could be robbed if the learners produce waves of language in a vacuum without interlocutors.

\section{The Concept Of Storytelling}

Storytelling according to Reinders (2011) is considered as an excellent verbal activity to help learners imagine and create plots as well as improve their speaking performance. In line with it, Akhyak \& Indramawan (2013) explain that storytelling has big impact on improving the learners' motivation to speak. Furthermore, Somdee and Suppasetseree
(2012) say that storytelling is an important activity to prepare the learners involve in speaking activities . Thus, telling story becomes one of the ways in classroom to learn a new language.

Beside that, this activity refers to the introducing vocabularies of the new language through constructing them to form story. Dujmovic (2006) explains that storytelling is considered as an important activity that demonstrates the power of words. In this case, words are used to make listeners imagine what is being told. Moreover, it uses words to enhance verbal expression, increases comprehension, and creates mental image.

\section{The Advantages Of Storytelling}

Kartiah, Rahman, \& Jabu (2014) mention that the use of storytelling strategy can integrate some language skills. For storytellers, it trains them to be creatively using their vocabularies to involve the listeners' imagination, meanwhile for listeners, they will imaginatively connect the story with their experiences. Fortunately, the activities in listening and reading stories can be followed up with speaking activities by retelling the story with the learners' own words. Therefore, through storytelling, the learners can demonstrate their ability to tell the story as well as selectively use colorful vocabularies to involve the listeners' imagination. In line with this opinion, Mall-Amiri \& Ghanbari (2014) \& Nia, Ghaemi, \& Afraz (2013) add that storytelling is a non-threatening way to activate the EFL learners with various language competence.

The activity of storytelling generally brings advantages to the learners. The teacher may use storytelling to create comfortable condition when he/she knows that the learners are moody to study. The teacher can also use storytelling to gain the learners' attention when their focus spread out. In short, the storytelling strategy is beneficial for learners in their learning activities. Pedagogically, storytelling strategy brings advantageous result to improve the learners speaking ability. Mixon \& Temu (2006) state that storytelling is an important way that can be applied to provoke the result of 
Journal of English Language and literature

Volume 6, Issue 2, September 2021

learners' learning. From the two points of view above, it can be understood that through storytelling, both of teacher and learners, can obtain benefit (Miller \& Pennycuff, 2008).

\section{How to Build up Storytelling Ability}

There are some ways to support the learners' ability to construct stories. These ways are expected to bind the learners' experiences with the story that they are going to tell.

There have been efforts to support the learners' ability in constructing stories, especially through school-based process. These efforts are expected to bind the learners' experiences with the story that they are going to tell. Rohmah (2012) gives beneficial solution to improve the learners' ability in storytelling that is asking learners to read the stories and make brief notes for the important events in the story. This step leads the learners to tell the stories using their own words. Besides, she also suggests 3 main activities that can train learners to be creatively constructing their stories, they are single-word story, sentence-story, and writing story in big circle.

\section{a. Single-word Story}

The single-word story is applied by asking learners to contribute word by word to construct the story. This means that a learner is expected to say a single word that is appropriate to keep the story continues. Technically, this activity can easily be done by asking learners to stand in line and sequentially every learner says a word to continue the story. If every learner has contributed a word in the story while the story still in progress, the activity will still continue by turning to the first learner to continue the story then followed by the next learner until the story complete.

\section{b. Sentence Story}

This kind of activity proposes learners to contribute their ideas in the form of sentences. So, a learner will say a sentence to continue the story until the story complete. Technically, the process is as same as in the single-word story, the only main different
p-ISSN 2540-8216, e-ISSN 2654-3745

https://journal.stibaiec-jakarta/ojs/index.php/jell

is that this activity requires every learner to contribute a sentence to improve the flow of the story. If the story has not completed yet, the turn continues to the first learner then followed by the next learner until the story complete.

\section{c. Writing Story in Big Circle}

The process of writing story in this activity is done in a circle. Therefore, the first activity is that requiring learners to form circles. In the process of constructing story, the learners will contribute their idea in the form of sentences. The process is as same as in the sentence story, the only different is that the process is done by writing their sentences to continue the story. Technically, a learner will write his/her sentence in the paper then gives that paper to the next learner to contribute their sentences. If the story have not completed yet, the turn can continue to the first learner then followed to the next learners until the story complete. From the 3 ways above, we can conclude that the storytelling technique requires learners to be actively contributing their ideas for the improvement of story.

In this present research, the researcher applied a new storytelling strategy namely Interactive Storytelling Strategy. The point was that the EFL learners were given a story to read. In their activities, the learners were expected to make display questions and referential questions concerning the story to ask their friends. The learners then share their question to their friends to answer. They could also ask for help to their friends when they found difficulties in the process of retelling the story, asking questions, and answering questions to make the flow learning activities runs interactively. In the last, the teacher gives them solution how they can solve their Improving the EFL Learners' Speaking.

\section{The Use of Pictures to tell story}

Heinich \& M. Molenda (1993) state that pictures as visual media are really helpful to make the learners speak. There are some reasons for using visual media in the teaching and learning process; in this case, in English teaching and learning process. Most 
of the people or learners are visually oriented. They explain that people learn about 10 percent from listening, but over 80 percent from what they see. More importantly, people are said to remember only about 20 percent of what they hear, but over 50 percent of what they see and hear.

Then, in relation to visual media, Kasbolah (1995) explain that young learners cannot handle abstract concept, but they can grasp concrete concepts easily. Therefore, visual media are worthwhile for the teaching learning process for young learners. The instructional media not only provide the necessary concrete experiences, but also help children integrate prior experiences, and relate the concrete to the abstract. She adds that one of the key reasons for using instructional media is to improve the relationship between concrete and abstract experiences.

\section{METHODS}

This study was carried out at Al Maulidiyah orphanage in Jatiasih Bekasi. The purpose of this research was to improve the EFL learners' speaking ability. The design of this study is Action Research by using the Interactive Storytelling Procedures. There were three main indicators as the main concern related to the learners' speaking ability taken from Aghdam and Farahani (2012), namely pronunciation, vocabulary and fluency. The stages used in this activity for two meetings were: (1) The learners were given a text and let them work in small group to understand it. (2) The teacher asked for the difficulties they faced and gave explanation. (3) The teacher gave a set of pictures similar to the previous reading text and asked them to create a story based on the pictures in group. (4) The teacher asked the learners to tell a story using the pictures given.

\section{FINDINGS}

After finishing the two meetings, the researcher found the data showing that some learners could finish the task of making storytelling using pictures and some others could not finish it. It can be seen from the table below:

Table 1. The Result of the Learners' Fulfilling the Storytelling task.

\begin{tabular}{|c|c|c|c|c|c|}
\hline \multirow[t]{2}{*}{ NO } & \multirow[t]{2}{*}{ NAME } & \multicolumn{2}{|c|}{ THE FIRST CYCLE } & \multicolumn{2}{|c|}{ THE SECOND CYCLE } \\
\hline & & Finished & Unfinished & Finished & Unfinished \\
\hline 1 & Student 1 & $\sqrt{ }$ & & $\sqrt{ }$ & \\
\hline 2 & Student 2 & & $\sqrt{ }$ & $\sqrt{ }$ & \\
\hline 3 & Student 3 & & $\sqrt{ }$ & & $\sqrt{ }$ \\
\hline 4 & Student 4 & $\sqrt{ }$ & & $\sqrt{ }$ & \\
\hline 5 & Student 5 & $\sqrt{ }$ & & $\sqrt{ }$ & \\
\hline 6 & Student 6 & $\sqrt{ }$ & & $\sqrt{ }$ & \\
\hline 7 & Student 7 & & $\sqrt{ }$ & $\sqrt{ }$ & \\
\hline 8 & Student 8 & & $\sqrt{ }$ & & $\sqrt{ }$ \\
\hline 9 & Student 9 & & $\sqrt{ }$ & & $\sqrt{ }$ \\
\hline 10 & Student 10 & $\sqrt{ }$ & & & $\sqrt{ }$ \\
\hline 11 & Student 11 & & $\sqrt{ }$ & $\sqrt{ }$ & \\
\hline 12 & Student 12 & & $\sqrt{ }$ & $\sqrt{ }$ & \\
\hline 13 & Student 13 & $\sqrt{ }$ & & $\sqrt{ }$ & \\
\hline 14 & Student 14 & & $\sqrt{ }$ & $\sqrt{ }$ & \\
\hline 15 & Student 15 & & $\sqrt{ }$ & & $\sqrt{ }$ \\
\hline & & 6 & 9 & 10 & 5 \\
\hline
\end{tabular}

The data showing about the number of learners who can finish the storytelling and those who can not finish the storytelling are categorized and put in percentage. 
Table 2. The Percentage of the Learners' Fulfilling the Storytelling task.

\begin{tabular}{|c|c|c|c|c|}
\hline & \multicolumn{2}{|c|}{ The First Cycle } & \multicolumn{2}{|c|}{ The Second cycle } \\
\hline & Finished & Unfinished & Finished & Unfinished \\
\hline Category & 6 & 9 & 10 & 5 \\
\hline Percentage & $40 \%$ & $60 \%$ & $66.7 \%$ & $33.3 \%$ \\
\hline
\end{tabular}

The learners' ability in making storytelling through pictures was put in three categories namely pronunciation, vocabulary, and fluency and some scoring such as very good, good, fair, and poor.

Table 3. The Learners' Storytelling Performance

\begin{tabular}{clcccccc}
\hline \multirow{2}{*}{ NO } & NAME & \multicolumn{2}{c}{ THE FIRST CYCLE } & \multicolumn{3}{c}{ THE SECOND CYCLE } \\
\cline { 2 - 7 } & & Pro & Voc & Flue & Pro & Voc & Flue \\
\hline & & & & & & VG & VG \\
\hline $\mathbf{1}$ & Student 1 & G & G & G & G & G & F \\
\hline $\mathbf{2}$ & Student 2 & F & F & P & F & F & F \\
\hline $\mathbf{3}$ & Student 3 & P & P & P & P & VG & VG \\
\hline $\mathbf{4}$ & Student 4 & G & VG & VG & G & VG & G \\
\hline $\mathbf{5}$ & Student 5 & G & F & F & G & F & G \\
\hline $\mathbf{6}$ & Student 6 & F & F & F & F & F & F \\
\hline $\mathbf{7}$ & Student 7 & P & P & P & P & P & P \\
\hline $\mathbf{8}$ & Student 8 & P & P & P & P & F & P \\
\hline $\mathbf{9}$ & Student 9 & F & F & P & F & G & F \\
\hline $\mathbf{1 0}$ & Student 10 & F & F & F & F & F & F \\
\hline $\mathbf{1 1}$ & Student 11 & F & F & P & F & F & F \\
\hline $\mathbf{1 2}$ & Student 12 & F & P & P & F & G & F \\
\hline $\mathbf{1 3}$ & Student 13 & F & G & F & G & F & F \\
\hline $\mathbf{1 4}$ & Student 14 & F & F & P & F & P & P \\
\hline $\mathbf{1 5}$ & Student 15 & P & P & P & P & P
\end{tabular}

* Pro = Pronunciation; VG = Very Good; Voc = Vocabulary; G = Good; Flue = Fluency; F= Fair; P = Poor

To see the improvement of the speaking ability performance especially when the learners making a storytelling can be seen from the percentage shown in the table below.

Table 4: The Percentage of Speaking Performance Indicators

\begin{tabular}{ccccccccccccc}
\hline $\begin{array}{c}\text { Speaking } \\
\text { Performance } \\
\text { Indicator scores: }\end{array}$ & Pro & $\boldsymbol{\%}$ & Voc & $\boldsymbol{\%}$ & Flue & $\boldsymbol{\%}$ & Pro & $\boldsymbol{\%}$ & Voc & $\boldsymbol{\%}$ & Flue & $\boldsymbol{\%}$ \\
\hline Very Good & 0 & $0 \%$ & 1 & $6.7 \%$ & 1 & $6.7 \%$ & 0 & $0 \%$ & 3 & $20 \%$ & 2 & $13.3 \%$ \\
\hline Good & 3 & $20 \%$ & 2 & $13.3 \%$ & 1 & $6.7 \%$ & 4 & $26.7 \%$ & 3 & $20 \%$ & 3 & $20 \%$ \\
\hline Fair & 8 & $53.3 \%$ & 7 & $46.7 \%$ & 4 & $26.7 \%$ & 7 & $46.7 \%$ & 7 & $46.7 \%$ & 7 & $46.7 \%$ \\
\hline Poor & 4 & $26.7 \%$ & 5 & $33.3 \%$ & 9 & $60 \%$ & 4 & $26.7 \%$ & 2 & $13.3 \%$ & 3 & $20 \%$ \\
\hline
\end{tabular}

\section{DISCUSSION}

Based on the research findings, the discussion will be divided into two parts, that is: the fulfilment of storytelling task and the speaking performance indicators in making storytelling.
From the two cycles, it shows that there was an improvement of fulfilling the task. It can be seen that the number of learners who could finish the task in making storytelling in the first cycle and second cycle was improving from $40 \%$ to $66.7 \%$ and the 
number of learners who could not finish the task in making storytelling was reduced from $60 \%$ to $33.3 \%$. This result was in line with other research projects conducted by researchers, such as that of Mokhtar, Halim \& Kamarulzaman (2010) and MallAmiri \& Ghanbari (2014). Those two research projects and many other studies agree that storytelling has many advantages in classroom learning.

In addition to the improvement of the learner number in fulfilling the task, the improvement of the speaking ability can also be seen from the improvement of some speaking performance indicators such as pronunciation, vocabulary, and fluency.

Those three speaking performance indicators were scored in four categories, namely: Very Good, Good, Fair, and Poor. From the first and the second cycles, the percentage of pronunciation shows that the number of learners who got very good (VG) and those who got poor $(\mathrm{P})$ are exactly the same. But for those who got good $(\mathrm{G})$ improves a bit from $20 \%$ to $26.7 \%$. At the same time, the percentage of vocabulary shows that the number of learners who got very good (VG) and good (G) improves respectively (from $6.7 \%$ to $20 \%$ and $13.3 \%$ to $20 \%$ ). And those who got fair (F) stay the same. In contrast, the number of learners who got poor $(\mathrm{P})$ lessens from $33.3 \%$ to $13.3 \%$. The last indicator, fluency, experiences much improvement. In the first cycle, the number of learners who got very good (VG) and good (G) is the same (6.7\%) and these improve to $13.3 \%$ and $20 \%$. While the number of learners who got fair (F) moves upward from $26.7 \%$ to $46.7 \%$. Otherwise, the number of learners who got poor (P) lessens from $60 \%$ to $20 \%$.

\section{CONCLUSION}

It can be concluded that from the two parts being discussed above both get improvement even though the percentage of improvement is different. Task fulfillment improves and speaking performance indicators which are divided into three parts such as pronunciation, vocabulary, and fluency also improve.

The researcher address suggestion to other or next researchers to conduct this kind of research in more detail so that many aspects can be analyzed not only the fulfillment of the task and the speaking performance indicator but also the classroom activities.

\section{REFERENCES}

Aghdam, Z. S and Farahani, A. A (2012). Speaking as an indicator of general proficiency in placement test. Journal of English and literature Vol. 3(6), pp. 136-149, October 2012

Ahmad, S. R. (2016). Importance of English Communication Skills. International Journal of Applied Reseacrh. 2016; 2(3): 478-480

Akhyak \& Indramawan, A. (2013). Improving the Students' English Speaking Competence through Storytelling (Study in Pangeran Diponegoro Islamic College (STAI) of Nganjuk, East Java, Indonesia). International Journal of Language and Literature, 1(2).

Aye, K. K. \& Phyu, K. L. (2015). Developing Students' Skills through Short Stories. Yangon University of Educational Research Journal. 5 (1), $1-11$.

Bailey, K. M. (2005). Practical English Language Teaching. New York: McGraw-Hill.

Brown, H. D. (2001). Teaching by Principles: An Interactive Approach to Language Pedagogy. New-York: Longman.

-------------(2004). Language Assessment Principles and Classroom Practices. New York: Pearson Education, Inc.

Dujmovic, M. (2006). Storytelling as a Method of EFL Teaching. Methodological Horizons, 1(1), $75-88$.

Goh, C. (2007). Teaching Speaking in the Language Classroom. Singapore: SEAMEO Regional Language Centre

Heinich,R, Molenda, M \& Russel, J. 1993. Instructional Media and the New Technologies of Instruction. Ottawa: John Willey \& Sons, Inc.

Kartiah, S. R., Rahman, M. A., \& Jabu, B. (2014). The Portrayal of Multiple Intelligence Theory 
in English Teaching Strategy for Indonesian Secondary School. Retrieved January 12, 2016 , from http://ojs.academypublisher.com/index.php/jlt r/article/view/13265

Kasbolah, K. 1995. Instructional Media for Young Learners of EFL. English Language Educational Journal, Volume 1, 1 July 1995.

Kurmaryati, S.E. (2009). Improving English Speaking Ability through Classroom Discussion for Students of MA NU BANAT KUDUS in the Academic Year 2008/2009. Jurnal Sosial Budaya Vol. 2 No. 2. 1 - 16.

Liao, G. (2009). Improvement of Speaking Ability through Interrelated Skills. English Language Teaching Journal. Vol. 2. No. 3: 11-14.

Mall-Amiri, B., \& Ghanbari, E. (2014). The Comparative Effect of Story Retelling and Role Playing on EFL Learners' Vocabulary Achievement and Reading Comprehension. IJLLALW, 6(3).

Miller, S., \& Pennycuff, L. (2008). The Power of Story: Using Storytelling to Improve Literacy Learning. Journal of Cross-Disciplinary Perspectives in Education. Retrieved from http://www.scoop.it/t/educating-the-educator

Mixon, M., \& Temu, P. (2006). First Road to Learning: Learning through Stories. English Teaching Forum, 43(2), 14-17.

Mokhtar, N. H., Halim, M. F. A., \& Kamarulzaman, S. Z. S. (2010). The Effectiveness of Storytelling in Enhancing Communicative Skills. Social and Behavioral Science, 18.
Richards, J.C. (2002). Methodology in Language Teaching. UK: Cambridge University Press.

Nia, Y. K., Ghaemi, H., \& Afraz, S. (2013). The Effect of Mixed-Up Stories on Vocabulary Learning and Retention of EFL Learners. Modern Journal of Language Teaching Methods, 3(2), 111-128.

Reinders, H. (2011). Digital Storytelling in the Foreign Language Classroom. ELTWO, 3.

Rohmah, Z. (2012). Teaching English Joyfully. Malang: Bintang Sejahtera Press.

Sepahvand, H. (2014). The Effect of Oral Reproduction of Short Stories on Speaking Skill in Iranian High School Students (Case Study: Khorram abda, Iran). International Journal of Science and Research (IJSR), 3 (1), $1847-1851$.

Somdee, M., \& Suppasetseree, S. (2012). Developing English Speaking Skills of Thai Undergraduate Students by Digital Storytelling through Websites. Retrieved January 11, 2016, from

http://www.litu.tu.ac.th/journal/FLLTCP/Proc eeding/166.pdfhttp://www.litu.tu.ac.th/journal /FLLTCP/Proceeding/166.pdf

Tahir, S. Z. A. (2015). Improving Students' Speaking Skill through Yahoo Messenger at University of Iqra Buru. International Journal of Language and Linguistics. 3 (3): $174-181$. doi: 10. 11648/j.ijll.20150303.20 
Sri Supeni and Ilham Dhony Pribadi

Enhancing Students' Speaking Ability through Collaborative Learning at Al Maulidiyah Orphanage in Jatiasih Bekasi

Intentionally Blank 